\title{
THE HYDROPOWER POTENTIAL AND FEASIBILITY ANALYSIS OF SOMBRIERO RIVER, RIVERS STATE, NIGERIA
}

\author{
M. Odje ${ }^{1,}{ }^{*}$, R. Uhunmwangho ${ }^{2}$ and K. Okedu ${ }^{3}$ \\ 1, 2, 3 Dept. of Electrical \& EleCtronics EnG'G, Univ. of Port Harcourt, Rivers STATE. NIGERIA \\ E-mail addresses: ${ }^{1}$ mattybouy007@gmail.com, ${ }^{2}$ tripodeng@yahoo.com, ${ }^{3}$ kenokedu@yahoo.com
}

\begin{abstract}
This paper examines the Sombriero River with a view of ascertain its discharge rate, potential hydro power can be derived and to provide a RETScreen-based financial viability analysis of adopting the river for a Micro Hydro Power Scheme. The river discharge was measured via the "Float Method Technique" while the river surface and mean velocities, derivable power as well as the scheme's viability were computed. The Sombriero river has the capacity to deliver $51 \mathrm{~kW}$ power, it would be a viable venture at a tariff price of $127.61 \$ / M W h$ and would be most suitable for Run-Off-River hydro scheme considering that it has low water head and substantial discharge.
\end{abstract}

Keywords: River discharge rate, hydro power potential, Financial viability

\section{INTRODUCTION}

Electrical energy is a major catalyst and driver of any viable economy as it is an inevitable input required for the technological and socio-economic development of a nation [1]. Hydropower generation dates back to the 19th century, first in Northumberland, England in 1878 and today, quite a good number of hydropower plants have been developed across the globe with these plants providing 2,998 billion kilowatt hours of clean and renewable energy in 2006 , approximately 20 percent of worldwide demand [2].

In Nigeria, the generation capacity fluctuates around 2500MW and 5000MW, which is far below estimated demand of 50,000MW to support the country's socioeconomic growth and development [3].

Adejumobi [4] stated that the collective installed capacity of power stations has fallen far below the country's electricity demand worsen by overwhelming population growth. To achieve sustainability, reliability and decentralized energy supply in Nigeria which has chunk of its populace living in remote and isolated rural communities with no access to electricity, renewable energy sources have been appraised as one of the guaranteed technology that must be aggressively harnessed since some of these rural areas located far from national grid have enormous unexploited hydro energy sources e.g. flowing rivers, streams, waterfall, biomass, solar and wind energy amongst others capable of bridging the energy gap in the country [5].

The nation is yet to substantially harnessed the huge potential power available with small hydro schemes inspite of its vast power deficit characterized by existing erratic supplies. This energy deficit is further widened by the failure of existing generating stations to operate at full installed capacities. More so, some rural localities fortunate to be on the grid system have very lengthy feeder lines owing to the remoteness, sparseness and distance of such rural communities from the power stations [6]. This also poses a serious technical and economic challenge for the utilities to construct, operate and maintain such feeder lines.

Consequently, these challenges have resulted in increased interest from the private and public sectors to seeking other alternative sources of energy particularly renewable energy sources with a view of providing decentralized generation (i.e. mini and offgrid system). Ravneet Kaur [7] stated that renewable energy is a sustainable, clean source of energy and the development of renewable energy is thriving due to failure of existing generation to meet load demands, inefficiency of existing grid system, shortfall in fossil energy and adverse environmental impacts. Ekpok Ekawa [8] maintained that a small hydro power (SHP) scheme is one of the favoured renewable energy technologies that is most appropriate for decentralized grid systems and distributed generations in rural dwellings owing to the fact that most rural centres are endowed with rivers, streams; waterfall and run-off waters with potent capacity to generate electric power if harnessed. Therefore, Small hydropower schemes have been on the front burner for clean energy sources that can fast-track rapid rural electrification 
considering the huge unharnessed rivers and streams in the rural settlement [9]. This paper aims at determine the river flow rate, available hydro power potential and the feasibility of harnessing the Sombriero River for Micro Hydropower generation. It also sorts to establish the chargeable electricity tariff at which the operation of the model would be financially viable for investors. The RETScreen International Clean Energy Project Analysis Software is a tool specifically aimed at simplifying pre-feasibility and feasibility analysis of clean energy technologies. The RETScreen software determines the core economic feasibility of the scheme in contracts with other options [10].

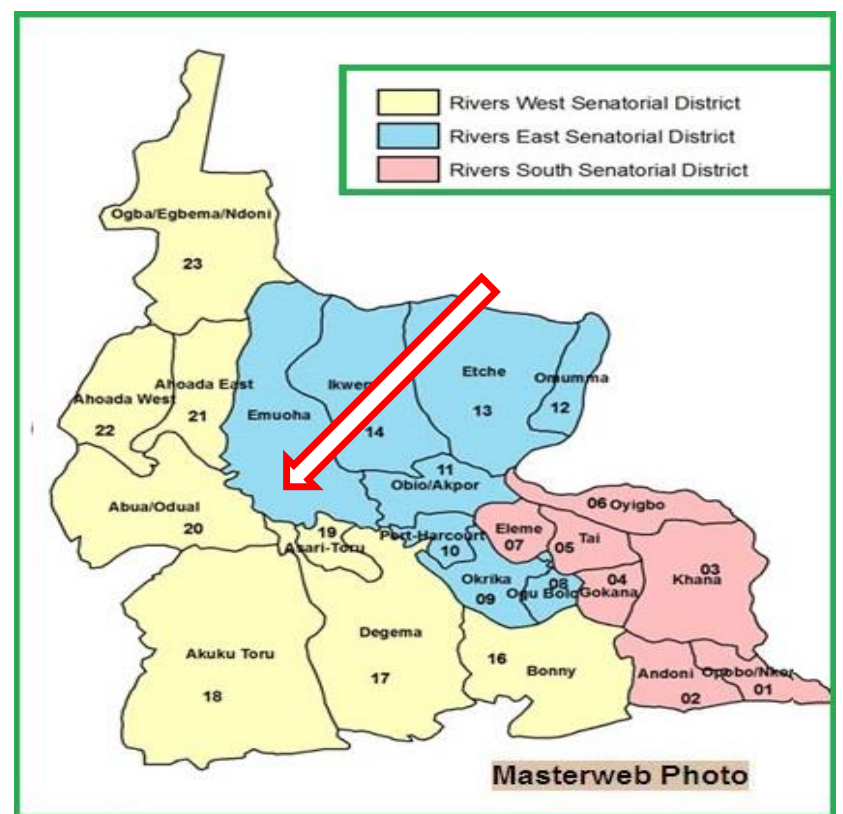

Figure 1: Map of Rivers State LGAs (Ahoada East \#21) [11]

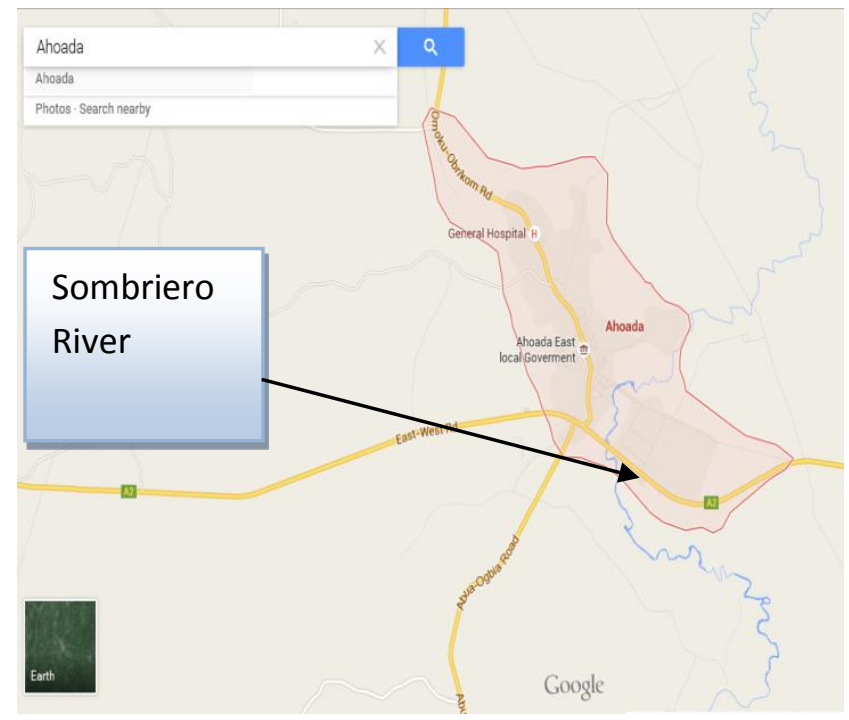

Figure 2: Map of Ahoada showing Sombriero River [13]

\section{RESEARCH METHODOLOGY}

\subsection{Location of Sombriero River}

The Sombriero River cuts through Ahoada town in River State Nigeria and lies on coordinates 5 $4^{\circ} 29^{\prime \prime}$ N and $6^{\circ} 39^{\prime} 35^{\prime \prime}$. Ahoada region is divided into two local government areas namely Ahoada West, with its seat in Akinima and Ahoada East, with its seat in Ahoada town where Sombriero River cuts through. Ahoada town in Ahoada East local government area of Rivers State Nigeria covers $341 \mathrm{~km}^{2}$ area [10]. It is an Ekpeye city and an administrative headquarters of the local government area, located northwest of Port Harcourt City. The Ekpeye are the indigenous people of Ahoada where the Ekpeye dialect is spoken. Figures 1 and 2 shows the google map location of Ahoada.

\subsection{Determination of river flow rate and cross-sectional area}

The Sombriero River flow rate measurement was achieved employing the "Float method Technique using a weighted piece of wood". The idea principally is to ascertain the duration it takes an object to float a specified distance downstream [15]. This technique measures river surface velocity and cross-section area at a selected spot. The mean velocity is obtained using a tolerance factor [16].

The tools and equipment used involve a GPRS device, a $30 \mathrm{~m}$ measuring tape, a 10 metres collapsible measuring rod, $100 \mathrm{~m}$ twine rope, 6 numbers of wooden floats, a marker pen, a biro pen, a note book, Sony digital camera; and at least three (3) persons.

During measurement and data collection at the site, the following steps were followed [17].

- A suitable river stretches and a straight reach with minimum turbulence measuring $22 \mathrm{~m}$ was selected.

- The start and end points of the reach were noted and marked.

- A piece of wood measuring $0.4 \mathrm{~m}$ by $0.2 \mathrm{~m}$ by $0.03 \mathrm{~m}$ was dropped into the river upstream marker to float.

- Record of time was taken by a stop-watch as soon as the object crosses the upstream marker and stopped when it crosses the downstream marker.

- The process was repeated for four (4) times and the different time records were documented and the average time determined for further calculations.

- Measure the river's width (at the downstream marked point) and calibration the width into 
sub-divisions as well as determination of corresponding river's depth of each subdivision.

The old East-West Road Bridge at Ahoada town was utilized in this respect for field data gathering. A 10 metres collapsible measuring rod was used to measure the depth at regular intervals of 1.5 metres across the river width which measures $33 \mathrm{~m}$ and a net head of $3.5 \mathrm{~m}$ approximately.

The river discharge rate is determined by first determining the surface velocity which is a ratio of the distance travelled by the object to the time it takes the object to travel such distance stated in equation I.

$$
V_{\text {surface }}=\frac{X}{T_{a v}} \mathrm{~m} / \mathrm{s}
$$

Where: $\mathbf{X}$ is the travel distance in metres, $\mathbf{T}_{\mathrm{av}}$ is the average travel time in seconds. Owing to the fact that surface velocities, $\mathbf{V}_{\text {surface }}$ generally, has higher values than mean velocity, then mean velocity is given by:

$$
V_{\text {mean }}=c . V_{\text {surface }} \mathrm{m} / \mathrm{s}
$$

Where $\mathbf{c}$ is a factor that takes care of the nature of the river bed. $\mathbf{c}=0.6$ for rough beds and 0.9 for smooth beds [16]. The cross-sectional area $\mathbf{A}$, of the river is determined by applying the trapezoidal rule of numerical method as:

$$
A=\frac{1}{n} \cdot \sum_{n=1}^{n} a_{n}=\frac{1}{n} \cdot \sum_{n=}^{n} \frac{d_{n} \cdot\left(b_{k}-b_{k-2}\right)}{2} m^{2}
$$

Where: $\mathbf{A}$ is the river cross sectional area $\left(\mathrm{m}^{2}\right)$ given as the average of the areas of the various trapeziums formed $\mathbf{a}$ is the area $\left(\mathrm{m}^{2}\right)$ of the trapezium formed at each sub-division and it varies directly with numbers of vertical depths, $\mathbf{n}$ is number of vertical depth at various sub-division across the river cross-sectional width usually an integer, $\mathbf{d}$ is the vertical depths ( $m$ ) from the river's surface to it bed, $\mathbf{b}$ is the horizontal distance $(\mathrm{m})$ from the river bank at one end of its width to the vertical depth spot per time being considered $\mathrm{k}$ is an integer given as $\mathrm{n}+1$

Equation (4) gives the river discharge rate.

$$
Q=V_{\text {mean }} . A=m^{3} / s
$$

In describing the power outputs for a small hydropower schemes, power equations for conventional hydro-power plant are equally applicable to small hydro-power scheme [18]. The potential output power is given by:

$$
P_{o}=g \cdot H \cdot Q \cdot \eta \quad k W
$$

Where: Po is the Potential Output Power in $\mathrm{kW}$ and $\eta$ is the overall efficiency of the hydropower scheme.
$\mathrm{H}$ is the available head in metres, $\mathrm{Q}$ is the design discharge rate in $\mathrm{m}^{3} / \mathrm{s}$ and $\mathrm{g}$ is the acceleration due to gravity given as $9.81 \mathrm{~m} / \mathrm{s}^{2}$.

\section{RESULTS PRESENTATION AND ANALYSIS}

Measurement of river flow rate utilizing the float method earlier explained in section 2.2, the following reading here tabulated was gotten for Sombriero River.

Table 1: Sombriero River Flow Measurement Data

(Period: April - July 2015), Travel distance $=22.0$ meters

\begin{tabular}{cc}
\hline Number of Trial & Travel Time, T (sec) \\
\hline $1^{\text {st }}$ & 28.58 \\
$2^{\text {nd }}$ & 26.09 \\
3rd & 28.42 \\
4 th & 26.57 \\
\hline
\end{tabular}

Applying the method of determining the river crosssectional area explained in section 2.2, the Sombriero River measured downstream has an average width (W) of 33.00 meters while the measured depths (d) of river

\begin{tabular}{|c|c|c|c|}
\hline $\mathrm{S} / \mathrm{N}$ & $\begin{array}{l}\text { River } \\
\text { Width } \\
\text { (m) - 'b' }\end{array}$ & $\begin{array}{c}\text { River } \\
\text { Depth } \\
\text { (m) - } \\
\text { 'd' }\end{array}$ & $\begin{array}{l}\text { Areas at various depths } \\
\qquad\left(m^{2}\right) \\
a_{n}=d_{n-1} \times\left(b_{n}-b_{n-2}\right) / 2\end{array}$ \\
\hline 0 & 0.00 & 0.00 & 0.00 \\
\hline 1 & 1.50 & 1.50 & 0.00 \\
\hline 2 & 3.00 & 1.75 & 2.25 \\
\hline 3 & 4.50 & 1.50 & 2.63 \\
\hline 4 & 6.00 & 2.00 & 2.25 \\
\hline 5 & 7.50 & 2.00 & 3.00 \\
\hline 6 & 9.00 & 1.95 & 3.00 \\
\hline 7 & 10.50 & 2.20 & 2.93 \\
\hline 8 & 12.00 & 2.60 & 3.30 \\
\hline 9 & 13.50 & 3.55 & 3.90 \\
\hline 10 & 15.00 & 3.90 & 5.33 \\
\hline 11 & 16.50 & 4.45 & 5.85 \\
\hline 12 & 18.00 & 4.65 & 6.68 \\
\hline 13 & 19.50 & 4.70 & 6.98 \\
\hline 14 & 21.00 & 4.35 & 7.05 \\
\hline 15 & 22.50 & 3.95 & 6.53 \\
\hline 16 & 24.00 & 3.55 & 5.93 \\
\hline 17 & 25.50 & 3.25 & 5.33 \\
\hline 18 & 27.00 & 2.60 & 4.88 \\
\hline 19 & 28.50 & 2.20 & 3.90 \\
\hline 20 & 30.00 & 2.25 & 3.30 \\
\hline 21 & 31.50 & 2.00 & 3.38 \\
\hline 22 & 33.00 & 0.00 & 3.00 \\
\hline
\end{tabular}
at regular interval of $1.50 \mathrm{~m}$ from the reference point 0 to $33 \mathrm{~m}$ are given in Table 2 .

Table 2: Sombriero River Cross-Sections at 1.50m intervals 
Simulating the records in Table 2 using Mat Lab software, the sharp of the Sombriero River bed is plotted as shown in Figure 3.

Applying equations 3 to data in Table 2, the computed value of cross section area of Sombriero River would be: $A=4.15 \mathrm{~m}^{2}$.

The Sombriero river surface and mean velocities is gotten by applying equations (1) and (2) to records of Table 2 using a tolerance factor of $0.6 . \mathrm{T}_{\mathrm{av}}=27.41 \mathrm{~s}$; $\mathrm{V}_{\text {surface }}=0.80 \mathrm{~m} / \mathrm{s} ; \mathrm{V}_{\text {mean }}=0.48 \mathrm{~m} / \mathrm{s}$

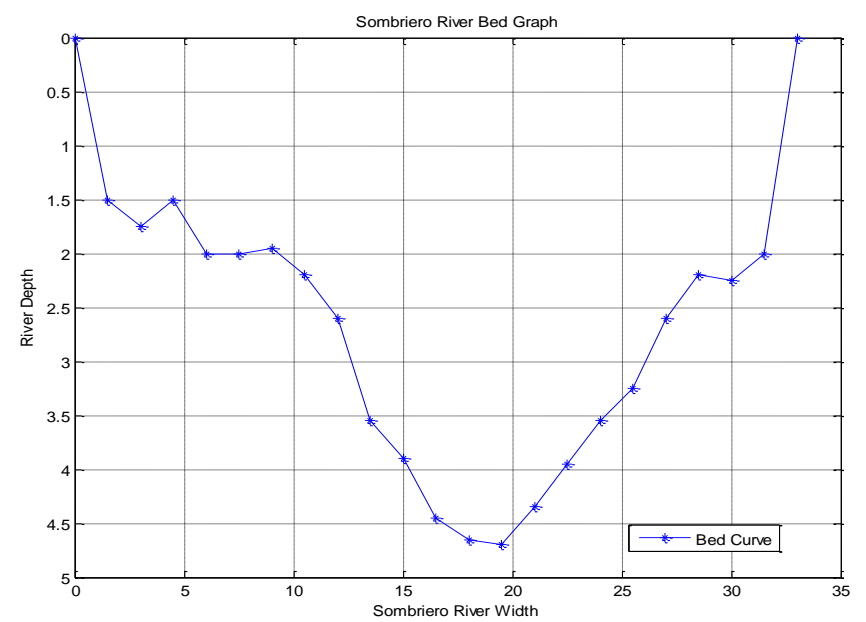

Figure 3: Sombriero River Bed Shape at old Ahoada Bridge, East West Road

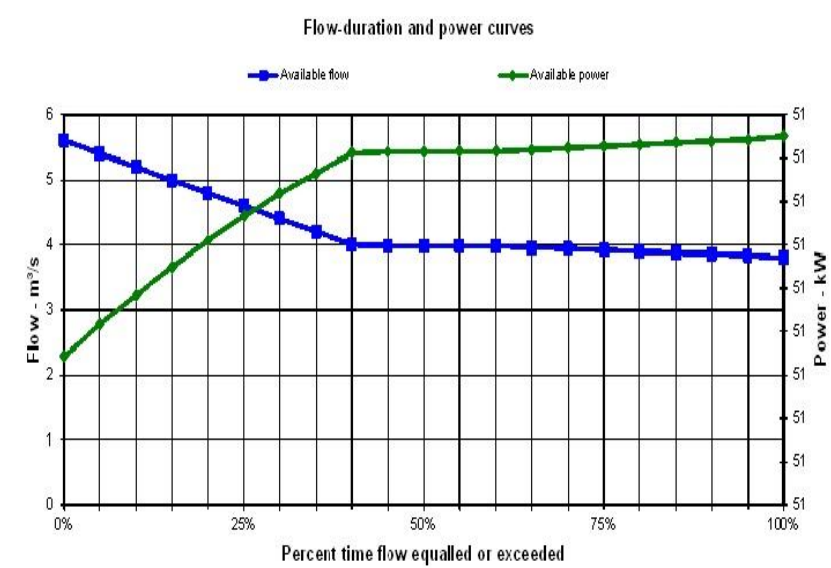

(a)

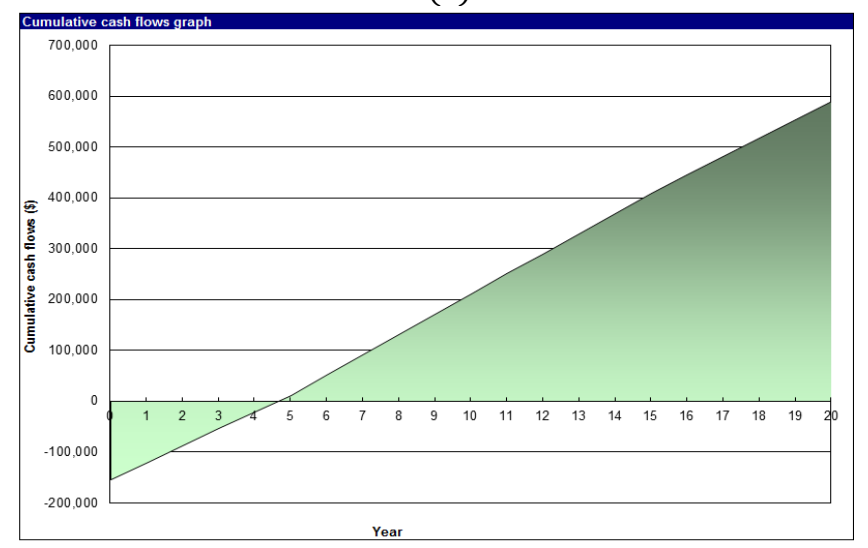

(b)

\begin{tabular}{|lcr|}
\hline Financial viability & $\%$ & \\
\hline Pre-tax IRR - equity & $\%$ & $26.1 \%$ \\
Pre-tax IRR - assets & $\%$ & $22.6 \%$ \\
After-tax IRR - equity & $\%$ & $19.5 \%$ \\
After-tax IRR - assets & & \\
& $\mathrm{yr}$ & 3.4 \\
Simple payback & $\mathrm{yr}$ & 4.6 \\
Equity payback & $\$$ & 920 \\
Net Present Value (NPV) & $\$ / y r$ & 211 \\
Annual life cycle savings & & 1.01 \\
Benefit-Cost (B-C) ratio & & 7.40 \\
Debt service coverage & $\$ / M W h$ & 127.61 \\
Energy production cost & &
\end{tabular}

(c)

Figure 4: (a) Flow duration and power curves (b) Cashflow graph (c) Financial viability indicators

The river flow rate (discharge rate) is obtained by using equation (4) as $\mathbf{Q}=1.99 \mathrm{~m}^{3} / \mathrm{s}$.

The estimate potential power generation from the Sombriero River using equation 5 at a conventional overall System efficiency of 0.75 and the Sombriero net head of $3.5 \mathrm{~m}$, would be: $\mathrm{P}_{\text {output }}=51.25 \mathrm{~kW}$.

Using RETScreen Renewable Software to perform financial simulation for Sombriero River inputting the computed data such as discharge rate, the following results in Figure 4 were obtained.

The Figure 4(a) shows the fluctuation of hydro generation with river flow. Also, Figure 4(a) confirmed that the available hydro potential with Sombriero River is $51 \mathrm{~kW}$ as earlier computed applying the power equations. Figure 4(b) provides the financial cash flow of the model. It shows that the operation of the scheme for about the first 5years is negative with a least negative value of about 150,000 USD. From the $5^{\text {th }}$ year upto the complete project life span of 20 years, the operation of this model will continue to have positive returns-on-investment that increases to a maximum cumulative value of about 590,000 USD.

The project financial viability is determined on the bases of a positive net present value (NPV), internal rate of return (IRR) not lesser than $+5 \%$, short payback-period and a benefit-cost ratio not less than 1 to indicate that the project economic value supersedes the economic cost.

From Figure 4(c), the NPV is 920USD (positive value), the IRR both equity and assets are $22.6 \%$ and $19.5 \%$ respectively after Tax and the benefit-cost ratio is 1.01 . The equity pay-back-period shows that after 4year and 6 months, the investors would recoup their investment. More so, the analysis show that the investment would pay-off at Sales tariff of 127.61USD per MWh. Based on this analysis, this model would be very viable to venture into by any interested investors. 


\section{CONCLUSION}

This article was able to demonstrate that the Sombriero River can generate about $51 \mathrm{kWh}$ of electric power at a discharge rate of $1.997 \mathrm{~m}^{3} / \mathrm{s}$. The development of this river for micro hydropower scheme would be a profitable venture at a sales tariff of N127.61USD/MWh. The scheme has a payback period of five years. The cumulative return on investment at the end of the $20^{\text {th }}$ year would be 590,000USD.

In order to improve on the accuracy of river flow rate measurement, standard current meter should be adopted in flow rate measurement instead of a wooden float object. More so, a lengthier hydrological data over 1-2 years if considered can further improve the accuracy of discharge measurement as well as the potential hydro power. Real time calculations and costing of actual hydro civil works, turbine-generator cost, hydraulic system and power transmission line costing would provide a more accurate estimate of total initial investment cost.

\section{REFERENCES}

[1] Oliver P. "Micro-Hydropower: Status and Prospects". IT Power Ltd, the Manor House, Chineham, Hants UK. Vol. 216 Issue 1, pp. 31-40, 2002.

[2] Painted Sky RC\&D Council Incorporation "A Practical Approach to Micro-Hydro Power in Colorado" An Educational Outreach Guidebook. Colorado, pp 1-27, 2001.

[3] Roseline Kela et al "Potentials of Small Hydro Power in Nigeria: The Current Status and Investment Opportunities". International Journals of Scientific \& Engineering Research, Vol. 3, pp. 1-5, 2001.

[4] Adejumobi I. A et al "Developing Small Hydropower Potentials for Rural Electrification". International Journal of Recent Research and Applied Studies, vol. 17 (1), pp 105 -110, 2013.

[5] Olayinka S. O. "Renewable and Sustainable Energy Reviews- Small Hydropower (SHP) Development in Nigeria: An Assessment" Elsevier Ltd, Vol. 15, pp 18, 2011.

[6] Adejumobi, I. A. and Shobayo, D. I. "Optimal Selection of Hydraulic Turbines for Small Hydroelectric Power Generation - A case study of Opeki River South Western Delta", Nigerian Journal of Technology, Vol. 34 (3), pp. 1-8, 2015.
[7] Ravneet K. and Jayati V. "A New Era in Electricity Production using Renewable Sources". International Journal of Emerging Technology and Advanced Engineering, Vol. 3 (2), pp 1-4, 2013.

[8] Ekpok E. E. "Small Hydro Power Projects and CDM Benefits: A Case Study of Obudu Plateau 1MW Small Hydro Project Nigeria". International Conference on Small Hydropower -Hydro Sri Lanka, pp 1-4, 2007.

[9] Celso Penche "Guide on How to Develop a Small Hydropower Plant". European Small Hydropower Association, pp 1-151, 1998.

[10] Canmet Energy Technology "Introduction to Clean Energy Project Analysis: RETScreen Engineering and Cases Textbook" Canada, pp 1-84, 2005.

[11] "Nigeria: Administrative Division - States and Local Government Areas" https://www.citypopulation.de/php/nigeriaadmin.php?adm2id. Accessed March 2, 2017

[12] "Images for Map of Rivers State Showing Local Government Areas" https://www.google.com.ng /search?q=map+of+rivers+state+showing+local +government+areas. Accessed March 2, 2017

[13] "Ahoada East Local Government Area" https://www.google.com.ng/maps/place/Ahoada +East+local+Goverment Accessed March 2, 2017

[14] Otuagoma, S.O., Ogujor, E. A. and Kuale, P. A., "Comparative Measurement of Stream Flows in the Ethiope River for Small Hydropower Development", Nigerian Journal of Technology, Vol. 34, No. 1, pp. 1- 9, 2015.

[15] Jamie Bartram and Richard Balance: "Water Quality Monitoring - A Practical Guide to the Design and Implementation of Freshwater Quality Studies and Monitoring Programmes: Hydrological Measurements". United Nations Environment Programme and the World Health Organization. pp. 1-10, 1996.

[16] Hydromatch "Flow Estimation for Stream and Small Rivers" http://www.hydromatch.com/ sites/default/files/downloads/DIY-flowmeasurement-guide.pdf. Accessed March 4, 2017

[17] Lonny Grafman "How to Measure Stream Flow Rate" http://www.appropedia.org/ How to measure stream flow rate. Accessed February 13, 2017

[18] Kurt Johnson and Andrea Hart: "Small Hydropower Handbook". Colorado Energy Office, 1580 Logan Street, Suite 100. pp. 1-50, 1973. 